\title{
Acral Lentiginous Melanoma of Foot and Ankle: A Clinicopathological Study of 7 Cases
}

\author{
XINGPEI HAO, JOON YIM, STEWART CHANG, ERIKA SCHWARTZ, SETH RUBENSTEIN, \\ CASEY FRISKE, SANA SHAMIM, ERIC MASTERNICK and GENE MIRKIN
}

Foot and Ankle Specialists of the Mid-Atlantic, LLC., Rockville, MD, U.S.A.

\begin{abstract}
Background/Aim: Acral lentiginous melanoma $(A L M)$ is a rare entity on the foot. This study aimed to reveal its clinical presentations, histopathology and treatment options. Materials and Methods: Seven cases of ALM involving foot were treated in our Institute in a 3-year period. Results: The patients' age ranged from 38 to 84 years, with a mean of 65 . The ratios of males to females and white to non-white were 4:3 and 5:2, respectively. Clinically, ALM presented as asymmetric, irregular shaped, black-brown, variegatedly discolored, papular, verrucoid, ulcerated or nodular lesions with or without pain. All ALMs were treated with either wide local excision (WLE) or toe amputation. Histologically, ALM was characterized by multiple single and nested atypical melanocytes growing along the dermal-epidermal junction, and extending into dermal layer in nodular growth pattern. Conclusion: ALM is a rare, asymmetric, irregularly bordered, variegatedly pigmented lesion. WLE or toe amputation is the standard treatment option.
\end{abstract}

Diagnosis of cutaneous malignant melanoma (CMM) has increased dramatically in the last several decades. Epidemiological analysis revealed that the incidence of CMM increased from 6.8 per 100,000 persons in 1973 to 20.8 per 100,000 persons in 2005 in the United States (1). Similar trends have been reported in other parts of the world (2). CMM has been histologically classified as four subtypes: Superficial spreading melanoma, occurring most often on the trunk, accounting for $70 \%$ of cases; Nodular melanoma, with

This article is freely accessible online.

Correspondence to: Dr Xingpei Hao, 1600 Gude Drive, Suite 205, Rockville, MD 20852, U.S.A. Tel: +1 3014174372, Fax: +1 3019337137, e-mail: xhao@footandankle-usa.com; Dr. Gene Mirkin, 10901 Connecticut Avenue, Suite 200, Kensington, MD 20895 U.S.A. Tel: +1 3019492000, Fax: +1 3019492002, e-mail: gmirkin@footandankle-usa.com

Key Words: Acral lentiginous melanoma, foot, pathology, surgical excision, toe amputation. a vertical growth pattern, accounting for $15 \%$; Lentigo malignant melanoma, occurring most often on the face, accounting for $13 \%$; and acral lentiginous melanoma (ALM) (3-5). ALM has been described as pigmented lesions on the distal region of the body, including the palms of the hands, soles of the feet and the nail subungual regions, and histologically characterized by a diffuse proliferation of large atypical melanocytes along the epidermal-dermal junction grown in a lentiginous (radial) pattern, with marked acanthosis and elongation of the rete ridges (4). ALM accounts for about $2-3 \%$ of all melanomas $(1,5)$. It has been reported that the age-adjusted incidence rate of ALM was 1.8 per million person-years (6). ALM is therefore a rare subtype of CMM. Due to its rarity, we present 7 cases of ALM involving foot and ankle with the aim to characterize its clinical presentations, histopathology, differential diagnosis and treatment options.

\section{Patients and Methods}

Seven cases of ALM on the foot and ankle diagnosed between Sept 1st, 2015 and August 30th, 2018 were retrieved from the database of Foot and Ankle Specialists of Mid-Atlantic, LLC (Xingpei Hao, $\mathrm{XPH}$ ). All treatment and prognostic data were provided by the referring individual patient care physician. All patients' HE and immunostained slides were evaluated again with confirmation of the original diagnoses (XPH). Tumor thickness was measured by the Breslow techniques (7) and the stage was defined according to the American Joint Committee on Cancer (AJCC) staging system $(8,9)$.

\section{Results}

Clinicopathological characteristics of ALM on the foot. As shown in Table I, seven cases of ALM on the foot including four males and three females were diagnosed in a three-year period. Five patients were white, one patient was Hispanic and one was African-American. The patients' age ranged from 38 to 84 years, with a mean and median age being 65 and 68 , respectively. Two tumors occurred on the soles, two on the dorsal skin of the 3rd toe, two on the tips of the hallux extending into nail beds, and one on the heel. Five tumors 
were located on the left side and two on the right side. The size of the tumors ranged from 0.4 to $2.5 \mathrm{~cm}$, with a mean and median size being 1.33 and $1.5 \mathrm{~cm}$, respectively. Four patients complained of pain. The onset of the pain was gradual, and the pain was aggravated by footwear and walking but was not alleviated by any treatment. The duration of symptoms from onset to evaluation ranged from one to 24 months with the mean and median were 5 and 2 months, respectively. Clinically, two ALMs on the plantar surface presented as irregular shaped, black-brown, unevenly discolored, thick hyperkeratotic verrucoid or flat lesions (Figure 1A, B). Two cases showed uneven black colored, asymmetric nodule or papule at the distal tips of hallux extending into matrix underneath the nail (Figure 1C, D). Another two patients exhibited discolored ulcerations on the heel or dorsal surface of the toe (Figure 1E). Three patients had noticeable medical histories of tumors, one with right breast cancer treated with modified radical mastectomy, one with Non-Hodgkin's lymphoma treated with CHOP therapy and one with appendiceal tumor treated with appendectomy. Two patients had long term histories of diabetes mellitus. The 38-year old female had significant family cancer histories including the mother with breast cancer, both maternal and paternal uncles and one cousin with melanomas. All patients were treated with surgical excision. Two ALMs on the plantar surface, one on the heel and one on the 3 rd toe were treated with wide local excision with safe margins free of tumors and sentinel lymph node biopsies, while three ALMs on the toes were treated with amputation of the toes. The 84-year female treated with hallux amputation died from cancer metastasis at follow-up of 16 months. All other patients were alive, without significant symptoms at follow-up from 12 to 48 months.

Histopathologically, five of 7 ALMs showed characteristics of multiple single and nested melanocytes with atypical size and shape arranged in a lentiginous growth pattern, which extended along the dermal-epidermal junction (Figure 2A). Multiple pagetoid single and nested dysplastic melanocytes were observed within all levels of the epidermis and dermis with irregularly distributed melanin, accompanied with epidermal hyperplasia with elongation of rete ridges, acanthosis and infiltrated lymphocytes (Figure 2A). Dysplastic melanocytes in nodular pattern grew at the papillary dermis and vertically down into the deeper level in the dermis (Figure 2B and C). Two of the seven ALMs were malignant melanomas in situ featured with multiple single and small clustered dysplastic melanocytes proliferating along the dermal-epidermal junction (Figure 2D, E and F). Immunostaining revealed that the malignant melanocytes were positive for MART-1 (Figure 2G), HMB-45 (Figure 2H), S-100 (Figure 2I), and focally positive for PHH3, but negative for cytokeratin AE1/AE3 (Figure 2J). The Breslow thickness available from 5 patients ranged from $1.48-3.7 \mathrm{~mm}$, with a mean thickness of $2.4 \mathrm{~mm}$. The Breslow thickness of the two ALMs in situ was not measured.

\section{Discussion}

We report seven cases of ALM on the foot and ankle with their clinical manifestation, histopathology and treatment. In our small series, the patients' age ranged from 38 to 84 years, with a mean of 65 . This is comparable with reported means of 62.7 (7) and 62.8 (6), and 63 (10). These data suggest that ALM occurs predominantly in populations older than 60 . The 38-year old white female patient had a strong family history of cancers where her mother had breast cancer and both her maternal and paternal uncles as well as one cousin had melanomas, suggesting that patients with a strong family history of multiple cancers may develop ALM younger than the general population.

Clinically, ALM can be located anywhere on the foot, including plantar surface, tips and dorsal surface of the toes, and heel. Most of the ALM present as an asymmetric, irregularly bordered, black-brown, unevenly discolored, thick hyperkeratotic verrucoid or flat papule or nodule, with or without pain, larger than $0.5 \mathrm{~cm}$. Ulceration can be noticed on the surface of the lesions.

Three of seven patients had a previous history of cancers before diagnosis of ALM: one had breast cancer, one NonHodgkin's lymphoma and one appendiceal tumor. Wolff $e t$ al. have shown that 61 out of 554 patients with melanomas $(11 \%)$ had second malignancies, with basal cell carcinomas being the most frequent tumor, followed by skin, gastrointestinal tract, genital, brain and lung cancer (11). Bae et al. have analyzed 432 melanomas and noticed 51 with secondary cancers (11.3\%); the most frequent secondary cancer was gastrointestinal cancer, followed by thyroid, lung, and breast (12). Patients with acral melanomas had a higher chance to have a secondary cancer compared with those with non-acral melanomas (12.8\% vs. 9.6\%) (12).

The standard treatment of patients with ALM involving foot is wide local excision (WLE) with safe margins free of tumor or toe amputation and sentinel lymph node (SLN) biopsy, depending on tumor location, size, depth of invasion and SLN status. Complete lymphadenectomy should be carried out when SLN biopsies are positive for lymphatic metastasis (13). Treatments for late stage ALM with spread to other organs include radiotherapy, cryotherapy and immunotherapy when surgical interventions fail (14). All of our patients were treated by either WLE for ALM on the plantar surface and heel, or toe amputation for ALM on the toes. The 38-year female with ALM on the surface of the 3rd toe was treated with WLE and skin graft upon patient's request.

Prognosis of ALM is determined by multiple factors, including patient's age, tumor location, size, Breslow 
Table I. Clinicopathological characteristics of patients with acral lentiginous melanoma on the foot and ankle.

\begin{tabular}{|c|c|c|c|c|c|c|c|}
\hline Patients & Age & Gender & Race & Clinical presentation & Histology of ALM & Treatment & Recurrence \\
\hline 1 & 68 & $\mathrm{~F}$ & White & $\begin{array}{l}\text { A painful, thick, black, verrucoid, } \\
\text { hyperkeratotic lesion under the right } \\
1 \text { st metatarsal head for } 2 \text { years } \\
\text { (Figure } 1 \mathrm{~A}), 2 \mathrm{~cm} \text {. Breast cancer } \\
\text { with modified radical right } \\
\text { mastectomy at } 44 .\end{array}$ & $\begin{array}{l}\text { Typical (Figure 2A) } \\
\mathrm{HMB}^{+} 45^{+}, \mathrm{MART}^{+} \text {, and } \\
{\mathrm{S} 100^{+}, \text {Fontana-Masson }} \\
\text { pigments }{ }^{+} \text {Thickness: } \\
1.67 \mathrm{~mm} 3 \mathrm{SLN}(-)^{\text {T2N0M0 }}\end{array}$ & $\begin{array}{c}\text { WLE with } 3 \\
\text { dissected SLNs }\end{array}$ & $\begin{array}{c}\text { None } \\
\text { (48 months) }\end{array}$ \\
\hline 2 & 63 & M & Hispanic & $\begin{array}{c}\text { A painful, irregular shaped, } \\
\text { dark, unevenly discolored, thick } \\
\text { hyperkeratotic flat papule with central } \\
\text { breakdown and dystrophy on the left } \\
\text { plantar heel for } 1 \text { month (Figure } 1 \mathrm{~B} \text { ), } \\
2.5 \mathrm{~cm} \text {. Numbness, tingling and } \\
\text { burning sensation in lower extremities. } \\
\text { Diabetes mellitus. }\end{array}$ & $\begin{array}{c}\text { Typical } \\
{\text { MART- } 1^{+},}_{\text {HMB- }^{+} 5^{+}} \\
\text {Thickness: } 1.48 \mathrm{~mm} \\
\text { T2bN0M0 }\end{array}$ & WLE & $\begin{array}{c}\text { None } \\
\text { (12 months) }\end{array}$ \\
\hline 3 & 77 & M & White & $\begin{array}{l}\text { A painful ulcer extending into } \\
\text { subcutaneous fat layer on his left } \\
\text { posterior inferior heel for } 2 \text { months, } \\
1.5 \times 1 \times 0.3 \mathrm{~cm} \text {. Non-Hodgkin's } \\
\text { lymphoma treated with CHOP } \\
\text { therapy } 10 \text { years ago. }\end{array}$ & $\begin{array}{l}\text { Biopsy and WLE: } \\
\text { Typical } \\
\text { S-100+, HMB- } 45^{+} \text {. } \\
\text { AE1/AE3- } \\
\text { Thickness: } 3.57 \mathrm{~mm} \text {. } \\
\text { T3bN0M0 }\end{array}$ & $\begin{array}{l}\text { WLE with } 2 \mathrm{~cm} \\
\text { margins with a } \\
\text { posterior calf flap } \\
\text { reconstruction and } \\
\text { skin graft from } \\
\text { the right thigh }\end{array}$ & $\begin{array}{c}\text { None } \\
\text { (48 months) }\end{array}$ \\
\hline 4 & 84 & $\mathrm{~F}$ & $\begin{array}{l}\text { African- } \\
\text { American }\end{array}$ & $\begin{array}{l}\text { A brown to black, gradually } \\
\text { raised, painful lesion with } \\
\text { irregular border and middle } \\
\text { ulceration at the tip and top } \\
\text { one third nail bed of right toe for } \\
1 \text { month (Figure } 1 \mathrm{C} \text { ), } 1.5 \times 1.0 \mathrm{~cm} \text {. } \\
\text { Matrixectomy due to painful injury, } \\
\text { loose toenail and paronychia } \\
6 \text { months ago. Diabetes mellitus. }\end{array}$ & $\begin{array}{c}\text { Typical with dermal } \\
\text { invasion (Figure } 2 \mathrm{~B}, \mathrm{C} \text { ) } \\
\text { HMB- } 45^{+} \\
\text {T2bN0M0 } \\
\text { Thickness: } 1.54 \mathrm{~mm}\end{array}$ & $\begin{array}{l}\text { Amputation of the } \\
\text { right hallux } \\
\text { with WLE }\end{array}$ & $\begin{array}{l}\text { Died from } \\
\text { cancer } \\
\text { metastasis at } \\
\text { follow-up of } \\
16 \text { months }\end{array}$ \\
\hline 5 & 38 & $\mathrm{~F}$ & White & $\begin{array}{l}\text { A discolored, gradually increased, } \\
\text { asymmetric, non-painful spot on } \\
\text { left medial 3rd toe for several } \\
\text { months. } 0.4 \mathrm{~cm} \text {. Mother with breast } \\
\text { cancer, both paternal and maternal } \\
\text { uncles and a cousin with melanoma. }\end{array}$ & $\begin{array}{l}\text { ALM in situ } \\
\text { (Figure 2D, 2E) } \\
\text { TISNOM0 }\end{array}$ & $\begin{array}{c}\text { WLE with } 5 \mathrm{~mm} \\
\text { margin and } \\
\text { skin graft }\end{array}$ & $\begin{array}{c}\text { None } \\
\text { (24 months) }\end{array}$ \\
\hline 6 & 48 & M & White & $\begin{array}{l}\text { A black, painless, uneven, asymmetric, } \\
\text { gradually increased spot with irregular } \\
\text { border and mild serous drainage on } \\
\text { left lateral distal dorsal tip extending } \\
\text { towards the nail matrix proximally } \\
\text { underneath the nail for } 2 \text { months } \\
\text { (Figure 1D), } 1 \times 1 \mathrm{~cm} \text {. }\end{array}$ & $\begin{array}{l}\text { ALM in situ (Figure 2F) } \\
\text { MART- } 1^{+} \text {(Figure 2G), } \\
\mathrm{HMB}^{-} 45^{+} \text {(Figure 2H), } \\
\text { S-100 (Figure 2I), focal } \\
\text { PHH3 }^{+}, \text {AE1/AE3- } \\
\text { (Figure 2J) } \\
\text { TISN0M0 }\end{array}$ & $\begin{array}{l}\text { Amputation } \\
\text { with WLE }\end{array}$ & $\begin{array}{c}\text { None } \\
\text { (20 months) }\end{array}$ \\
\hline 7 & 78 & M & White & $\begin{array}{l}\text { A painless growth with central } \\
\text { ulceration, yellow thick moist tissue } \\
\text { distally and mild erythema proximally } \\
\text { on the medial dorsal side of left } 3 \text { rd } \\
\text { toe for } 3 \text { months (Figure } 1 \mathrm{E} \text { ), } \\
0.3 \times 0.4 \mathrm{~cm} \text {. An appendectomy for } \\
\text { tumor. Family history with cancer. }\end{array}$ & $\begin{array}{l}\text { Biopsy and } \\
\text { amputation: Typical } \\
\mathrm{HMB}^{-} 45^{+}, \mathrm{S}-100^{+} \text {, } \\
\text { vimentin }{ }^{+}, \mathrm{SOX} 10^{-} \text {, } \\
\text { AE1/AE3 }{ }^{-} \\
2 \text { SLN (-) from } \\
\text { left groin } \\
\text { Thickness: } 3.7 \mathrm{~mm} \\
\text { T3bN0M0 }\end{array}$ & $\begin{array}{l}\text { Toe amputation } \\
\text { with WLE and } \\
2 \text { SLNs dissection }\end{array}$ & $\begin{array}{c}\text { None } \\
\text { (36 months) }\end{array}$ \\
\hline
\end{tabular}

Typical acral lentiginous melanoma (ALM): Multiple single and nested melanocytes with varied size and shape presented in dermal-epidermal junction with irregularly distributed melanin; AE1/AE3, cytokeratin AE1/AE3; HMB, human melanoma black; MART: melanoma antigen recognized by T cells; PHH3, phosphorylated histone H3; SLN, sentinel lymph node; SOX10, SRY-related HMG-box 10; WLE, wide local excision. 


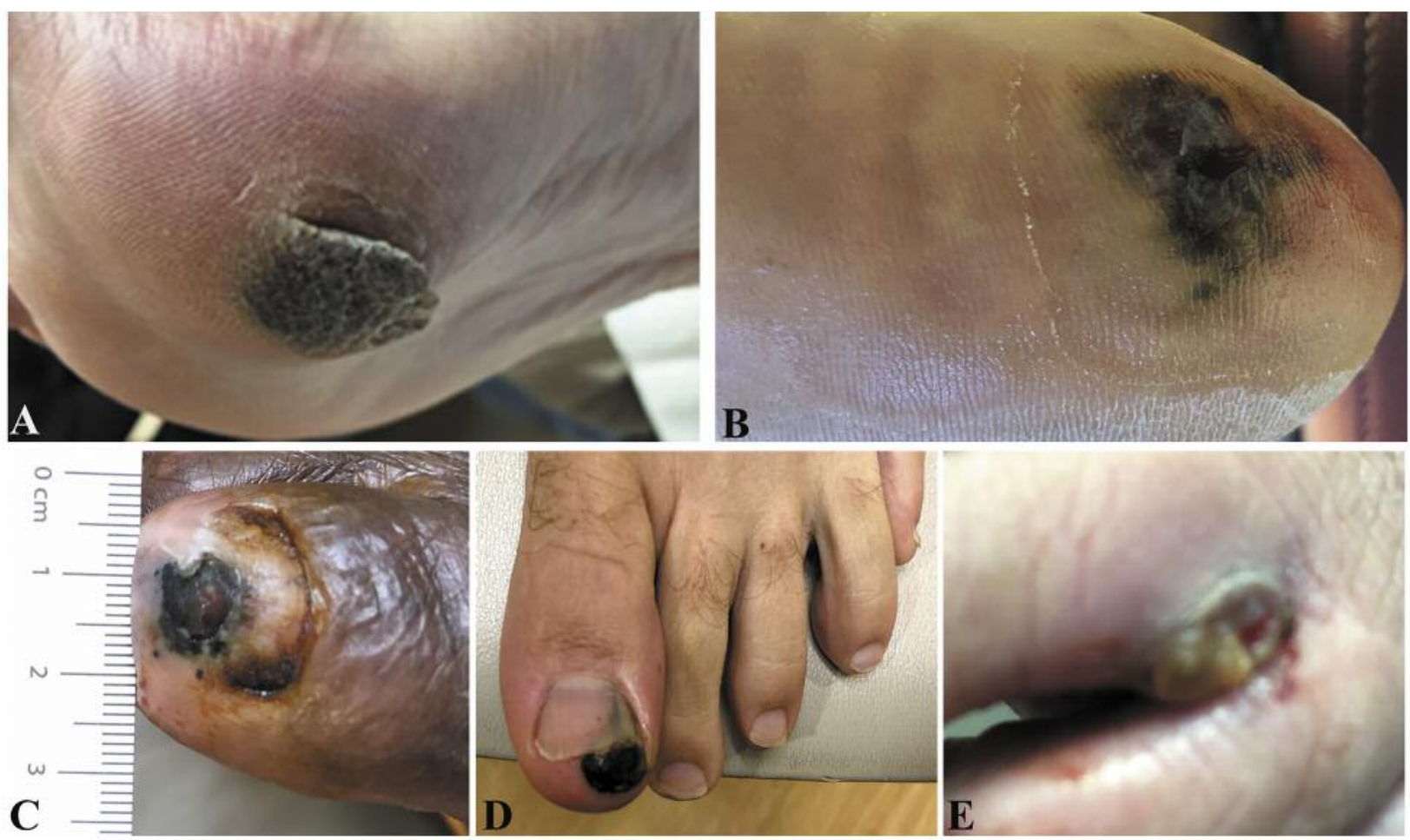

Figure 1. Clinical presentations of acral lentiginous melanoma. A. A thick, black, rough and verrucoid lesion on the plantar surface (patient 1); B. An irregular shaped, dark, unevenly discolored papule with central breakdown and dystrophy on the plantar heel (patient 2); C. A brown to black, raised nodule with irregular border and middle ulceration at the tip and distal one third nail bed of right big toe (patient 4); D. A black, uneven, asymmetric papule with irregular border on lateral distal dorsal tip extending towards the nail matrix proximally underneath the left first toenail (patient 6); E. A raised, ulcerated tissue with yellow thick moist tissue and mild erythema on the medial dorsal side of the 3rd toe (patient 7).

thickness, and SLN involvement (15). SLN status is the most important factor to predict recurrence and survival of ALM patients $(13,15)$. It has been reported that the overall five- and ten-year melanoma-specific survival rates of acral melanoma were lower than that of cutaneous malignant melanoma (80.3\% vs. $91.3 \%$ and $67.5 \%$ vs. $87.5 \%$, respectively) (6). The 84-year old African-American female with nodular growth on the right hallux died from metastasis at follow-up of 16 months after toe amputation. This patient had a long history of DM and was at a late stage when diagnosed. All other patients had no recurrence at follow-up, from 12 to 48 months.

Histologically flate or papular ALMs are characterized by multiple dysplastic single and nested melanocytes growing lentiginously along the dermal-epidermal junction. The pagetoid single cell and nested cells can infiltrate up into any level of the epidermis and down into dermis. Nodular ALM is featured with atypical melanocytes growing in the papillary dermis and vertically invading down to a deeper level in the dermis. ALM in situ shows multiple single or small clustered dysplastic melanocytes growing in the epidermal layer along the dermal-epidermal junction.
Immunostaining for biomarkers of malignant melanocytes displayed positive staining for MART-1, HMB-45, S-100, and focal PHH3 but negative staining for cytokeratin AE1/AE3, which are helpful for the diagnosis and differential diagnosis.

ALM needs to be differentiated from other benign and malignant conditions including chronic foot diabetic ulcer, acral lentiginous nevus, pyogenic granuloma, paronychia, hematoma, onychomycosis, ischemic necrosis, palmoplantar wart, poroma, schwannoma, and squamous cell carcinoma. Biopsies for histological evaluation with the assistance of specific stains and biomarkers contribute to the final diagnosis.

The pathogenesis of ALM is still unclear. It is believed that trauma may play a role during melanomagenesis. Previous penetrative injury has been reported to be associated with the development of ALM (16). However, this association did not gain support from another report (17). Interestingly, two recent studies have suggested that longterm physical or mechanical stresses may be related to the formation of melanoma on the plantar surface of foot in 


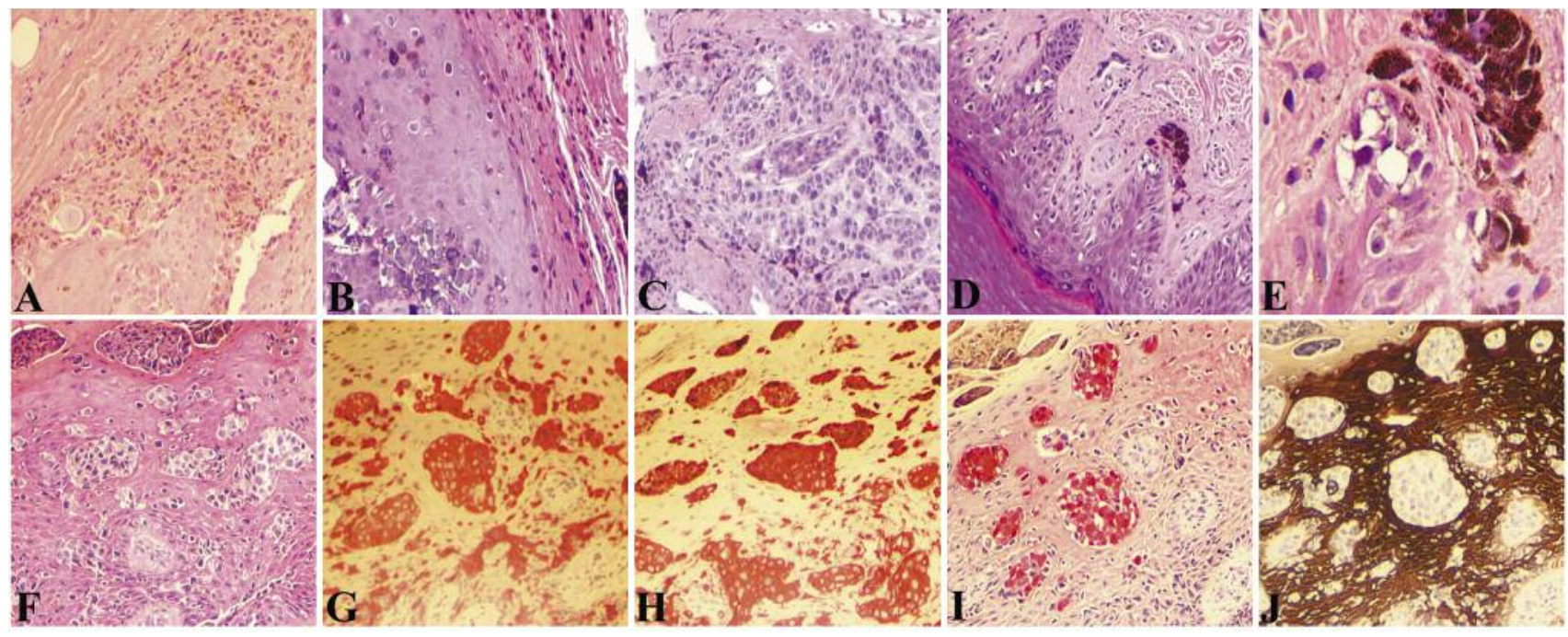

Figure 2. Histopathology of acral lentiginous melanoma. A. Multiple dysplastic single and nested melanocytes growing lentiginously along the dermal-epidermal junction (patient 1) (HE, 100×1); B: Nodular acral lentiginous melanoma (ALM) featured with multiple atypical single melanocytes infiltrating all layers of epidermis and a cluster of dysplastic melanocytes proliferating at the papillary dermis (patient 4) (HE, 100 $\times 1)$; C. Malignant melanocytes invading down into deep dermis (patient 4) (HE, 100×1); D and E. ALM in situ showing multiple single and small clusters of dysplastic melanocytes growing in the epidermal layer along the dermal-epidermal junction (patient 5) (HE, D: 100xl, E: 400×1); F. ALM in situ showing multiple pagetoid single and nested cells infiltrating up into all levels of the epidermis (patient 6) (HE, 100 $\times 1)$. Immunostaining for biomarkers of malignant melanocytes being positive for MART-1 (Figure 2G, 100×1, the malignant melanocytes were positively stained with Fast red), HMB-45 (Figure 2H, 100×1, the malignant melanocytes were positively stained with Fast red), S-100 (Figure 2I, 100×1, the malignant melanocytes were positively stained with Fast red), but negative for keratin AE1/AE3 (Figure $2 \mathrm{~J}, 100 \times 1$, the malignant melanocytes were negatively stained with DAB whereas the keratinocytes were positively stained with DAB, which served as internal positive control) (patient 6).

Korean (18) and Japanese populations (19). These data suggested that constant pressure, stress, friction, maceration and irritation to the sole may contribute to the melanomagenesis on the sole. The 84-year African-American female with diabetes mellitus had a history of bruising and loose right big toenail with paronychia, and she was treated with phenol and alcohol based matrixectomy and cephalexin prior to her diagnosis of ALM six months ago. The patient gradually recovered without events from infection until discoloration and drainage at the tip of toe were noticed. Punch biopsy confirmed the diagnosis of ALM. This case suggests that trauma and infection may play a role in the formation of melanoma in view of the consequential development from infection to the melanoma.

Genetic factors may also play a significant role in the genesis of ALM. Our 38-year white female patient had a strong family history of different kinds of cancers, including a mother with breast cancer, both paternal and maternal uncles and one cousin with melanomas, which indicates that ALM may be related to genetic changes in this particular family. Moreover, three of seven ALMs had previous medical history of cancers. Mutations of BRAF, NRAS, KIT and PTEN have been reported in ALM with a frequency being $17 \%, 15 \%, 15 \%$ and $4 \%$, respectively (20). Mutations in $\mathrm{B} R A F, N R A S$ and KIT are involved in the activation of mitogen-activated protein kinase (MAPK) and the phosphatidylinositol-3 kinase (PI3K)/Akt pathways, leading to the deregulated cellular proliferation, differentiation and apoptosis, which may contribute to the development of ALM (21). Since tumorigenesis results from dysfunctions of multiple oncogenes and tumor suppressor genes, further investigation is needed to reveal the genes involved in the formation of ALM.

The association between primary cutaneous melanoma and melanocytic nevus has been reported with a frequency between $4 \%$ and $72 \%(10,22-24)$. A 15 -year prospective study involving 832 patients showed that $54.2 \%$ of primary melanomas were associated with melanocytic nevi, and the patients with multiple nevi had a higher frequency of nevus associated melanomas (25). Multiple moles on the soles or other parts of the body have been linked to the development of ALM (16). Our 38-year white female patient had multiple dark brown macules with ill-defined borders and asymmetric pigment network under dermoscope on the central chest, left 5th metatarsal-phalangeal joint, right lateral heel, lower back and right posterior thigh, as well as round to oval, regular to 
slightly asymmetric, uniformly-pigmented brown macules scattered on the face, neck, trunk, and extremities, suggesting that ALM may arise from transformation from preexisting proliferative neval cells in this patient.

In conclusion, ALM on the foot is a rare entity of malignant melanoma in older populations. It most often occurs on the plantar surface and toes, and presents as asymmetric, irregularly bordered, black to brown papule or raised nodule. Wide local excision or amputation is the standard treatment option. Patients with previous history of malignancies or family history of melanoma or multiple asymmetric moles need to be screened regularly for early diagnosis and treatment.

\section{Conflicts of Interest}

The Authors have no conflicts of interest to declare regarding this study.

\section{Authors' Contributions}

Xingpei Hao: Study conceptualization, data collection, analysis and interpretation, writing and revising the article; Joon Yim: Diagnosis, data collection, analysis and interpretation, article revision; Stewart Chang, Erika Schwartz, Seth Rubenstein, Casey Friske, Sana Shamim, and Eric Masternick: Patient care, data collection, analysis and interpretation, article revision. Gene Mirkin: Study conceptualization, patient care, data collection, analysis and interpretation, coordination, article revision.

\section{References}

1 Surveillance, epidemiology and end results (seer) program. National cancer institute, dccps, surveillance research program, cancer statistics branch; apr. 2008 seer*stat database. Available at: https://www.seer.cancer.gov/

2 Lens MB and Dawes M: Global perspectives of contemporary epidemiological trends of cutaneous malignant melanoma. Br J Dermatol 150(2): 179-185, 2004. PMID: 14996086. DOI: 10.1111/j.1365-2133.2004.05708.x

3 Clark WH Jr., From L, Bernardino EA and Mihm MC: The histogenesis and biologic behavior of primary human malignant melanomas of the skin. Cancer Res 29(3): 705-727, 1969. PMID: 5773814.

4 Reed R: Acral lentiginous melanoma. New Concepts in Surgical Pathology of the Skin, edited by Hartman W, Rood R. John Wiley \& Sons: New York pp. 89-90, 1976.

5 Markovic SN, Erickson LA, Rao RD, Weenig RH, Pockaj BA, Bardia A, Vachon CM, Schild SE, McWilliams RR, Hand JL, Laman SD, Kottschade LA, Maples WJ, Pittelkow MR, Pulido JS, Cameron JD and Creagan ET: Malignant melanoma in the 21st century, part 1: Epidemiology, risk factors, screening, prevention, and diagnosis. Mayo Clin Proc 82(3): 364-380, 2007. PMID: 17352373. DOI: $10.4065 / 82.3 .364$

6 Bradford PT, Goldstein AM, McMaster ML and Tucker MA: Acral lentiginous melanoma: Incidence and survival patterns in the united states, 1986-2005. Arch Dermatol 145(4): 427-434, 2009. PMID: 19380664. DOI: 10.1001/archdermatol.2008.609
7 Breslow A: Thickness, cross-sectional areas and depth of invasion in the prognosis of cutaneous melanoma. Ann Surg 172(5): 902-908, 1970. PMID: 5477666. DOI: 10.1097/0000 0658-197011000-00017

8 Balch CM, Buzaid AC, Soong SJ, Atkins MB, Cascinelli N, Coit DG, Fleming ID, Gershenwald JE, Houghton A, Jr., Kirkwood JM, McMasters KM, Mihm MF, Morton DL, Reintgen DS, Ross MI, Sober A, Thompson JA and Thompson JF: Final version of the american joint committee on cancer staging system for cutaneous melanoma. J Clin Oncol 19(16): 3635-3648, 2001. PMID: 11504745. DOI: 10.1200/JCO.2001.19.16.3635

9 Balch CM, Gershenwald JE, Soong SJ, Thompson JF, Atkins MB, Byrd DR, Buzaid AC, Cochran AJ, Coit DG, Ding S, Eggermont AM, Flaherty KT, Gimotty PA, Kirkwood JM, McMasters KM, Mihm MC Jr., Morton DL, Ross MI, Sober AJ and Sondak VK: Final version of 2009 ajcc melanoma staging and classification. J Clin Oncol 27(36): 6199-6206, 2009. PMID: 19917835. DOI: $10.1200 / J C O .2009 .23 .4799$

10 Phan A, Touzet S, Dalle S, Ronger-Savle S, Balme B and Thomas L: Acral lentiginous melanoma: A clinicoprognostic study of 126 cases. Br J Dermatol 155(3): 561-569, 2006. PMID: 16911282. DOI: 10.1111/j.1365-2133.2006.07368.x

11 Wolff $\mathrm{J}$ and Wollina $\mathrm{U}$ : Second malignancies in melanoma patients in thuringia. J Eur Acad Dermatol Venereol 14(6): 479483, 2000. PMID: 11444270.

12 Bae SH, Seon HJ, Choi YD, Shim HJ, Lee JB and Yun SJ: Other primary systemic cancers in patients with melanoma: Analysis of balanced acral and nonacral melanomas. J Am Acad Dermatol 74(2): 333-340, 2016. PMID: 26584878. DOI: 10.1016/ j.jaad.2015.09.047

13 Lee DY, Lau BJ, Huynh KT, Flaherty DC, Lee JH, Stern SL, O'Day SJ, Foshag LJ and Faries MB: Impact of completion lymph node dissection on patients with positive sentinel lymph node biopsy in melanoma. J Am Coll Surg 223(1): 9-18, 2016. PMID: 27236435. DOI: 10.1016/j.jamcollsurg.2016.01.045

14 Goydos JS and Shoen SL: Acral lentiginous melanoma. Cancer Treat Res 167: 321-329, 2016. PMID: 26601870. DOI: 10.1007/ 978-3-319-22539-5_14

15 Egger ME, McMasters KM, Callender GG, Quillo AR, Martin RC, 2nd, Stromberg AJ and Scoggins CR: Unique prognostic factors in acral lentiginous melanoma. Am J Surg 204(6): 874879; discussion 879-880, 2012. PMID: 23022254. DOI: 10.1016/j.amjsurg.2012.05.013

16 Green A, McCredie M, MacKie R, Giles G, Young P, Morton C, Jackman L and Thursfield V: A case-control study of melanomas of the soles and palms (australia and scotland). Cancer Causes Control 10(1): 21-25, 1999. PMID: 10334638.

17 Kaskel P, Kind P, Sander S, Peter RU and Krahn G: Trauma and melanoma formation: A true association? Br J Dermatol 143(4): 749-753, 2000. PMID: 11069451. DOI: 10.1046/j.13652133.2000.03770.x

18 Jung HJ, Kweon SS, Lee JB, Lee SC and Yun SJ: A clinicopathologic analysis of 177 acral melanomas in koreans: Relevance of spreading pattern and physical stress. JAMA Dermatol 149(11): 1281-1288, 2013. PMID: 24067997. DOI: 10.1001/jamadermatol.2013.5853

19 Minagawa A, Omodaka T and Okuyama R: Melanomas and mechanical stress points on the plantar surface of the foot. $\mathrm{N}$ Engl J Med 374(24): 2404-2406, 2016. PMID: 27305207. DOI: 10.1056/NEJMc1512354 
20 Zebary A, Omholt K, Vassilaki I, Hoiom V, Linden D, Viberg L, Kanter-Lewensohn L, Johansson CH and Hansson J: KIT, NRAS, BRAF and PTEN mutations in a sample of swedish patients with acral lentiginous melanoma. J Dermatol Sci 72(3): 284-289, 2013. PMID: 23993026. DOI: 10.1016/j.jdermsci.2013.07.013

21 Reddy BY, Miller DM and Tsao H: Somatic driver mutations in melanoma. Cancer 123(S11): 2104-2117, 2017. PMID: 28543693. DOI: $10.1002 /$ cncr.30593

22 Stolz W, Schmoeckel C, Landthaler $\mathrm{M}$ and Braun-Falco $\mathrm{O}$ : Association of early malignant melanoma with nevocytic nevi. Cancer 63(3): 550-555, 1989. PMID: 2643457. DOI: 10.1002/10970142(19890201)63:3<550::aid-cncr2820630325>3.0.co;2-a

23 Rhodes AR, Harrist TJ, Day CL, Mihm MC Jr., Fitzpatrick TB and Sober AJ: Dysplastic melanocytic nevi in histologic association with 234 primary cutaneous melanomas. J Am Acad Dermatol 9(4): 563-574, 1983. PMID: 6630618. DOI: 10.1016/ s0190-9622(83)70171-4
24 Skender-Kalnenas TM, English DR and Heenan PJ: Benign melanocytic lesions: Risk markers or precursors of cutaneous melanoma? J Am Acad Dermatol 33(6): 1000-1007, 1995. PMID: 7490345. DOI: 10.1016/0190-9622(95)90294-5

25 Haenssle HA, Mograby N, Ngassa A, Buhl T, Emmert S, Schon MP, Rosenberger A and Bertsch HP: Association of patient risk factors and frequency of nevus-associated cutaneous melanomas. JAMA Dermatol 152(3): 291-298, 2016. PMID: 26536613. DOI: 10.1001/jamadermatol.2015.3775

Received September 21, 2019

Revised October 3, 2019

Accepted October 4, 2019 